\title{
$\mathrm{A} 1-1 \% \mathrm{Mn}$ 合金の熱間加工で形成する析出物とその分散状態
}

\author{
田中 宏樹 ${ }^{1 *}$. 佐々木 勝寛 ${ }^{1} \cdot$ 立山 真司 ${ }^{1}$
}

Journal of The Japan Institute of Light Metals, Vol. 71, No. 12 (2021), 549-554

(C) 2021 The Japan Institute of Light Metals

\section{Formation and dispersion of precipitates during hot deformation in $\mathrm{Al}-1 \% \mathrm{Mn}$ alloys}

\author{
Hiroki TANAKA $^{1 *}$, Katsuhiro SASAKI ${ }^{1}$ and Shinji TATEYAMA ${ }^{1}$
}

In this study, precipitation behavior in hot workings on $\mathrm{Al}-1 \% \mathrm{Mn}$ alloy was investigated. It has been identified specimens used in this study show thermally stabilized substructures after plain strain compression (PSC) test as a hot working. PSC tests were carried out between $300^{\circ} \mathrm{C}$ and $500^{\circ} \mathrm{C}$. By using small angle $\mathrm{X}$-ray scattering (SAXS) method, dispersion state of precipitations formed in hot workings were estimated. It was considered minute precipitations less than $10 \mathrm{~nm}$ in diameter were formed in hot worked areas. These minute precipitations were increased with increasing in compression temperature. In invariant area heated at $400^{\circ} \mathrm{C}$, precipitations less than $10 \mathrm{~nm}$ were not identified. By using of HAADF-STEM, these minute precipitations less than $10 \mathrm{~nm}$ were confirmed, and it was cleared due to EDS analysis the precipitations consist of four elements such as aluminum, manganese, iron and silicon.

(Received July 1, 2021 Accepted September 24, 2021)

Keywords: aluminum manganese alloys; plain strain compression; small angle x-ray scattering; high angle annular dark field scanning; hot deformation

\section{1. 緒言}

一般に，アルミニウム合金展伸材を高温で加熱すると等軸 の再結晶粒組織となり強度低下が生じる。熱間加工時に熱的 安定な下部組織を形成させることで加熱後も繊維状組織が維

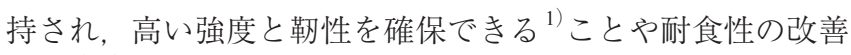
効果 $^{2-3)}$ が知られている。遷移元素のマンガンを主要添加元 素とする 3000 系アルミニウム合金は缶ボディ材等に広く使 われていて, その再結晶挙動を制御することは重要な課題で ある。これまでの研究を参考にすると, 均質化処理条件を変 えることで第二相粒子の分散状態を変化させ，その後の熱間 加工組織における回復挙動を調査している ${ }^{4)-5)}$ 。熱間加工中 に生じる析出挙動も熱的安定な下部組織形成に影響すると考 えられるが，調査例が少なく不明な点が多い。

筆者らは高純度（4Nベース）地金と 99.5\%（1050ベース） 地金にマンガンを $1 \%$ 添加した供試材を準備して, 平面ひず み圧縮 (PSC) 試験 ${ }^{6}$ により, 熱的安定な下部組織形成条件

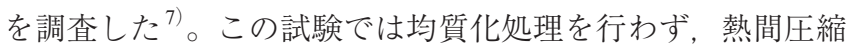
時に生じる析出挙動の影響を明らかにすることを目的とし た。その結果, 4Nベース合金では, PSC試験後の導電率変化 が小さく，析出は少ないと判断した。1050ベース合金は圧縮 部の導電率が上昇し, 非圧縮部よりも析出が促進すると判断
した。 $\mathrm{PSC}$ 試験後に $500^{\circ} \mathrm{C}$ 熱処理（ソルトバス）を行うと $4 \mathrm{~N}$ ベース合金は再結晶するが，1050ベース合金は再結晶せず， 熱的安定な下部組織形成状態に有意差が認められた。

本研究では 1050 ベース合金の高温圧縮部に形成する析出 状態を明らかにすることを目的とした。圧縮部に形成する析 出物は非常に微細であると考え, X線小角散乱法（Small Angle X-ray Scattering, SAXS ${ }^{8)}$ での調査を行った。小角散乱 の回折強度プロファイルを解析することで, ナノメートルサ イズの粒子分布を推定できる。

\section{2. 実 験方法}

本研究に用いたアルミニウム合金の成分を Table 1 に示す。 一般的な半連続鋳造により一辺が $175 \mathrm{~mm}$ 幅の鋳塊を造塊し た。この鋳塊から厚さ $10 \mathrm{~mm}$, 幅 $20 \mathrm{~mm}$, 長さ $50 \mathrm{~mm}$ の試験 片を調製した。なお, 熱間加工中の溶質元素の析出挙動を明 らかにするため, これらの鋳塊に均質化処理は行わなかっ

Table 1 Chemical composition of specimens.

$(\operatorname{mass} \%)$

\begin{tabular}{c|c|c|c|c|c|c|c|c}
\hline \hline $\mathrm{Si}$ & $\mathrm{Fe}$ & $\mathrm{Cu}$ & $\mathrm{Mn}$ & $\mathrm{Mg}$ & $\mathrm{Cr}$ & $\mathrm{Zn}$ & $\mathrm{Ti}$ & $\mathrm{Al}$ \\
\hline 0.16 & 0.34 & $<0.01$ & 0.99 & $<0.01$ & $<0.01$ & $<0.01$ & 0.01 & Bal. \\
\hline
\end{tabular}

${ }^{1}$ 株式会社UACJ R\&Dセンター（４455-8670 愛知県名古屋市港区千年3-1-12） Research \& Development Division, UACJ Corporation（3-1-12, Chitose, Minato-ku, Nagoya, 455-8670)

*責任著者E-mail : tanaka-hiroki@uacj.co.jp 


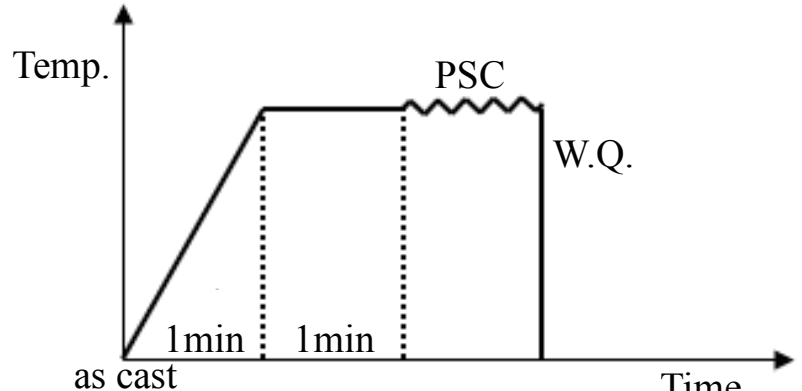

(a) Heat pattern

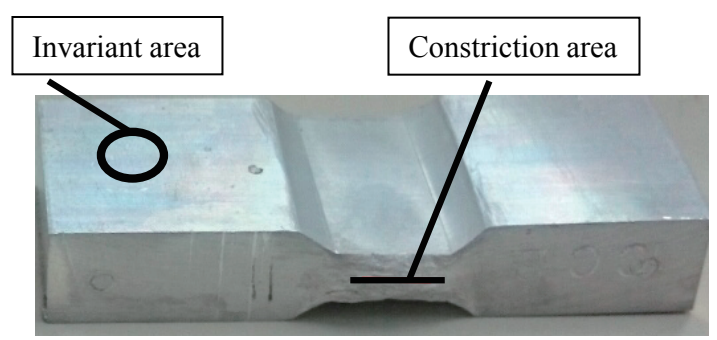

(b) Specimen appearance after PSC

Fig. 1 Experimental procedures on (a) heating pattern of PSC test and (b) measurement arias of the specimens.

た。これは，均質化処理で形成する析出物と熱間加工中に形 成する析出物の混在を避けるためである。PSC 試験条件は前 報7) で報告した通りで，その処理方法を Fig. 1 (a) に示す。300 ${ }^{\circ} \mathrm{C}, 400^{\circ} \mathrm{C}$ および $500^{\circ} \mathrm{C}$ の温度で厚さ $5 \mathrm{~mm}$ まで圧縮を行っ た。ひずみ速度は $1 \mathrm{~s}^{-1}$ とした。導電率の測定位置を Fig. 1 (b) に示す。圧縮部の中心部（Constriction area）と非圧縮部の表 層（Invariant area）で測定した。微細化合物の分散状態を小角 散乱法 ${ }^{8)}$ で調査した。小角散乱測定はあいちシンクロトロン 放射光で実施した。その測定条件を Table 2 に示す。小角散乱 強度は測定サンプルの厚さの影響を受けるため，本報では測 定值をサンプル厚さで除した值で比較した。測定に使用した サンプルの厚さを Table 3 に示す。小角散乱強度プロファイル は解析ソフトIrenaを用いて微細化合物の分散状態を解析し た ${ }^{9)}$ 。散乱べクトル $(Q)$ は $(1)$ 式で, 小角散乱強度 $I(Q)$ は（2）式で示される ${ }^{10)}$ 。本報では化合物の形態を球状と仮 定し，サイズ分布関数として対数正規分布を用いた。Irenaで

Table 2 Measurement method of Aichi synchrotron radiation.

\begin{tabular}{c|c}
\hline \hline Beam line & BL8S3 \\
Analysis method & SAXS \\
Detector & R-AXIS \\
Aperture & $2.5 \mathrm{~mm}$ \\
Camera length & $1126.09 \mathrm{~mm}$ \\
WAVE LENGTH & $0.92 \AA$ \\
\hline
\end{tabular}

Table 3 Specimen thickness on SAXS measurement.

$(\mathrm{mm})$

\begin{tabular}{c|c|c|c}
\hline \hline Invariant area & \multicolumn{3}{|c}{ Constriction area } \\
\hline $400^{\circ} \mathrm{C}$ & $300^{\circ} \mathrm{C}$ & $400^{\circ} \mathrm{C}$ & $500^{\circ} \mathrm{C}$ \\
\hline 0.455 & 0.336 & 0.474 & 0.356 \\
\hline
\end{tabular}

は, 球体の半径 $\mathrm{R}$ を変化させた粒度分布（P）を求めて（2） 式から小角散乱強度を計算して実測值にフィッティングさ せ，化合物の分散状態を推定する。

$$
Q=4 \pi \sin \theta / \lambda
$$

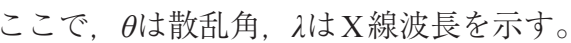

$$
I(Q)=\rho^{2} \int_{0}^{\infty} F^{2}(Q) N(R) d R
$$

ここで, $\rho$ は電子密度, $F(Q)$ は試料からの散乱 X線の振幅, $\mathrm{N}(R)$ は半径 $\mathrm{R} の$ 粒子数を示す。

PSC 試験後の析出状態を確認するため, HAADF-STEM （High-Angle Annular Dark Field Scanning TEM）観察を行った。 この観察像は透過電子のうち高角に散乱したものを環状の検 出器で検出することにより得られ, 原子量の大きい元素を含 む場合に明るいコントラストが得られる ${ }^{11)}$ 。観察はFEI製 Tecnai Osirisで, 加速電圧 $200 \mathrm{kV}$ で行った。EDS分析はSTEM プローブ径を $1 \mathrm{~nm}$ 以下とした。

\section{3. 実 験 結 果}

\section{1 導電率}

導電率の測定結果をTable 4 に示す。非圧縮部より圧縮部の 方が導電率は高く, 圧縮部でより多く析出していることが推 察できる。PSC温度が高いほど，圧縮部の導電率は高くなる。 非圧縮部も, $500^{\circ} \mathrm{C}$ 加熱では導電率の上昇が認識できる。 $\mathrm{PSC}$ 試験条件から, 約 0.5 秒の圧縮加工時間で析出が生じている と推定できる。

\section{2 小角散乱}

Fig. 2 に測定した小角散乱強度を示す。X軸は散乱べクトル （ $Q$ ）を示す。 $Q$ 值が 0.2 以下で散乱強度が低下しているのは, 検出器を保護する目的でスクリーン遮蔽しているためであ

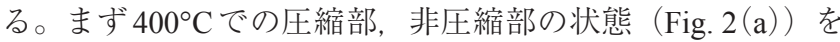
比較すると， $Q$ 值が 0.2 から 1.0 の範囲で曲線の傾きが異なる ことがわかる。非圧縮部の傾きが圧縮部より大きくなってい る。次に圧縮部の状態 (Fig. 2(b) ) を比較する。 $300^{\circ} \mathrm{C}$ 圧縮部 と $400^{\circ} \mathrm{C}$ 圧縮部の散乱強度は近い傾きを持った曲線となって いる。 $500^{\circ} \mathrm{C}$ 圧縮部は $Q$ 值が 1.0 以上で $400^{\circ} \mathrm{C}$ 圧縮部と $300^{\circ} \mathrm{C}$ 圧縮部の間の強度を示し, 他の条件とは異なる曲線形状とい える。

Fig. 3 に小角散乱強度の実測值と Irenaでモデル計算して フィッティングした結果を示す。いずれの条件も Irenaで適切 なパラメータを設定することで良好なフィッティング状態が 得られている。この結果から化合物の分散状態を予測した結 果をFig. 4 に示す。横軸は化合物の半径でナノメートル $(\mathrm{nm})$ 表示をしている。縦軸は体積率を示している。化合物の粒度 分布（1P）を点線で示し, 複数の粒度分布が想定された場合

Table 4 Difference on electrical conductivity between invariant and constriction areas.

(\%IACS)

\begin{tabular}{c|c|c|c|c|c|c}
\hline \hline \multirow{2}{*}{ as cast } & \multicolumn{3}{|c|}{ Invariant area } & \multicolumn{3}{c}{ Constriction area } \\
\cline { 2 - 7 } & $300^{\circ} \mathrm{C}$ & $400^{\circ} \mathrm{C}$ & $500^{\circ} \mathrm{C}$ & $300^{\circ} \mathrm{C}$ & $400^{\circ} \mathrm{C}$ & $500^{\circ} \mathrm{C}$ \\
\hline 30.5 & 30.5 & 30.6 & 31.1 & 30.9 & 31.1 & 31.5 \\
\hline
\end{tabular}




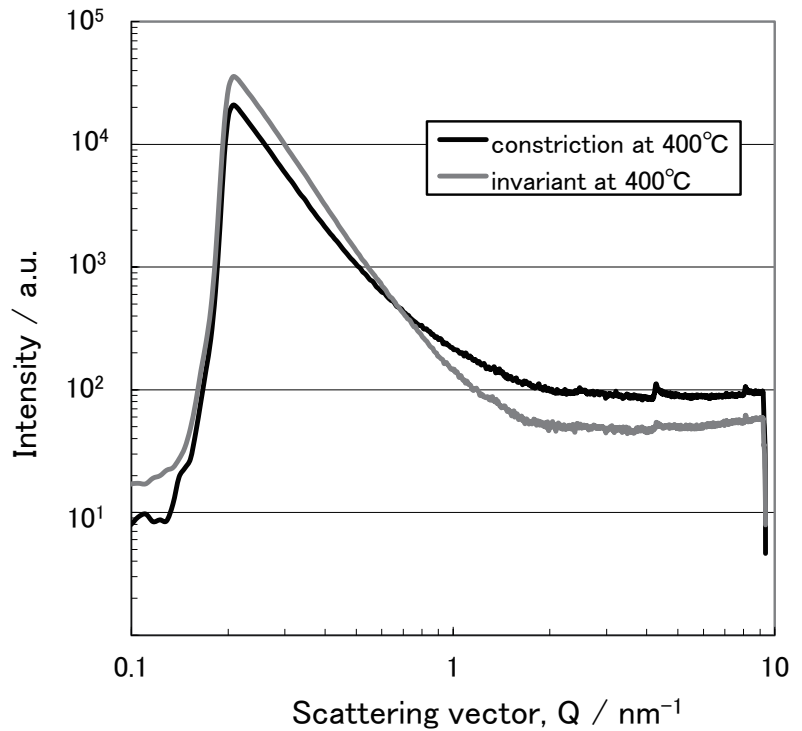

(a) Constriction and invariant area at $400^{\circ} \mathrm{C}$

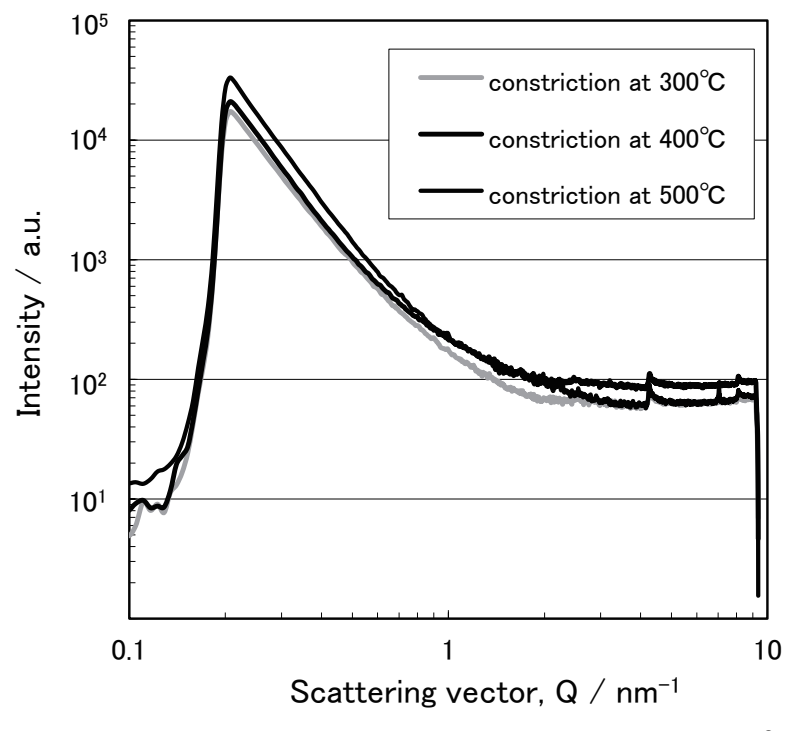

(b) Constriction area at 300,400 and $500^{\circ} \mathrm{C}$

Fig. 2 SAXS profiles of PSC test pieces (a) constriction and invariant areas at $400^{\circ} \mathrm{C}$ and (b) constriction areas at 300 , 400 and $500^{\circ} \mathrm{C}$.

（2P，3P）はその合計を実線で示している。 $400^{\circ} \mathrm{C}$ 非圧縮部 (Fig. 4 (a)）は $25 \mathrm{~nm}$ 付近にピークのある分散状態を示す。一 方, $400^{\circ} \mathrm{C}$ 圧縮部（Fig. 4(b)）は $25 \mathrm{~nm}$ 付近と $3 \mathrm{~nm}$ 付近の $2 つ$ のピークを持つ分散状態となっている。 $300^{\circ} \mathrm{C}$ 圧縮部（Fig. 4 (c)）は $400^{\circ} \mathrm{C}$ 圧縮部と同じ分散状態であるが， $3 \mathrm{~nm}$ 付近の ピーク值は $400^{\circ} \mathrm{C}$ 圧縮部より小さい。 $500^{\circ} \mathrm{C}$ 圧縮部（Fig. 4 (d)）は $3 \mathrm{~nm}$ 付近に大きなピークがあり，30 nm付近に小さな ピークおよび $50 \mathrm{~nm}$ 付近にもピークが認められる。 $3 \mathrm{~nm}$ 付近 のピークは圧縮部のみで認められ，その体積率は $300^{\circ} \mathrm{C}$ 圧縮 部 $<400^{\circ} \mathrm{C}$ 圧縮部 $<500^{\circ} \mathrm{C}$ 圧縮部の順に大きくなる。

\subsection{STEM 観察}

Fig. 4 で推定した微細化合物の状態をHAADF-STEMで確認 した。Fig. 5 にHAADF-STEM像を示す。 $400^{\circ} \mathrm{C}$ 圧縮部（Fig. 5 (b)）には $40 \mathrm{~nm}$ 程度の化合物と $10 \mathrm{~nm}$ 以下の微細化合物が認 められる。400 ${ }^{\circ} \mathrm{C}$ 非圧縮部（Fig. $5(\mathrm{a})$ ) には, $10 \mathrm{~nm}$ 以下の微
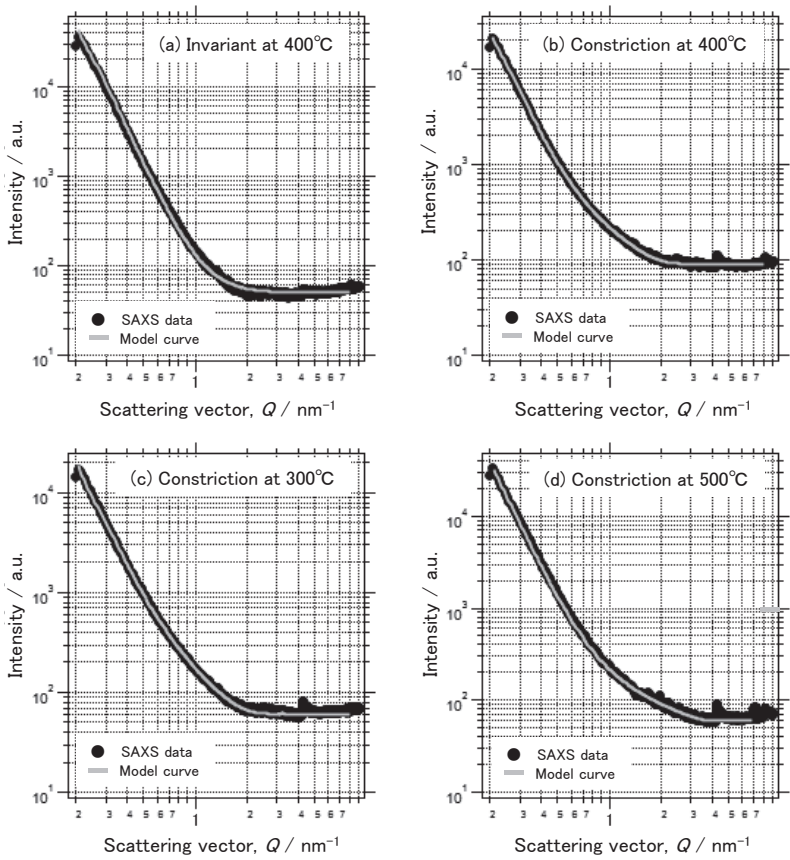

Fig. 3 Experimental and calculated values on SAXS data (a) invariant at $400^{\circ} \mathrm{C}$, (b) constriction at $400^{\circ} \mathrm{C}$, (c) constriction at $300^{\circ} \mathrm{C}$ and (d) constriction at $500^{\circ} \mathrm{C}$.

細化合物は確認できなかった。 $300^{\circ} \mathrm{C}$ 圧縮部 (Fig. 5 (c)) にも $400^{\circ} \mathrm{C}$ 圧縮部と同様に $40 \mathrm{~nm}$ 程度の化合物と $10 \mathrm{~nm}$ 以下の微細 化合物が認められる。 $500^{\circ} \mathrm{C}$ 圧縮部（Fig. 5(d)）には50〜100 $\mathrm{nm}$ 程度のサイズを有する化合物が認められる。Fig. 4 (d) に 示す $500^{\circ} \mathrm{C}$ 圧縮部には $10 \mathrm{~nm}$ 以下の化合物も存在することが 予想される。Fig. 5(d) の一部を拡大した状態をFig. 6に示す。 $500^{\circ} \mathrm{C}$ 圧縮部にも $10 \mathrm{~nm}$ 以下の微細化合物が存在している。 Fig. 5(d) 内に, このような微細化合物の集まりが複数個所確 認できる。HAADF-STEM像で確認できる化合物に対して, EDS 分析で構成元素を確認した。Fig. 7 に $400^{\circ} \mathrm{C}$ 圧縮部の HAADF-STEM像と EDS 分析結果を示す。確認できる微細化 合物は Al-Mn-Fe-Si系四元化合物であった。 $300^{\circ} \mathrm{C}$ 㧍よび 500 ${ }^{\circ} \mathrm{C}$ 圧縮部にみられる化合物も $\mathrm{Al}-\mathrm{Mn}-\mathrm{Fe}-\mathrm{Si}$ 系四元化合物で あった。HAADF-STEM像で確認できる微細化合物の形成過 程を次のように考える。所定温度に加熱 (1分), 保持（1分） 中に $10 \mathrm{~nm}$ 以上の化合物が形成し, PSC 試験中にそれらが成 長することと, 新たに $10 \mathrm{~nm}$ 以下の化合物が形成する。 $500^{\circ} \mathrm{C}$ 圧縮では化合物の成長速度が速く, PSC 直前までに形成した 化合物の多くが PSC 試験中に $50 \sim 100 \mathrm{~nm}$ 程度のサイズまで 成長することと，新たに $10 \mathrm{~nm}$ 以下の化合物が形成し， Fig. 4 （d）で示す分散状態になった。これらの形態を考慮すると, PSCを行った熱間加工中の析出は, 熱間加工前に形成してい た化合物の周囲に析出する場合と, 新たに微細析出する場合 の二通りがあることが分かった。

\section{4. 考察}

PSC 試験の圧縮部で導電率が高くなる（析出する）場合, 熱的安定な下部組織が形成することを前報》で報告し, Fig. 8 に示すメカニズムを提案した。加工中に移動する転位に析出 が生じて転位の移動が抑止され，別なすべり面を移動する転 位と反応した場合に不動転位化することで，熱的安定な下部 

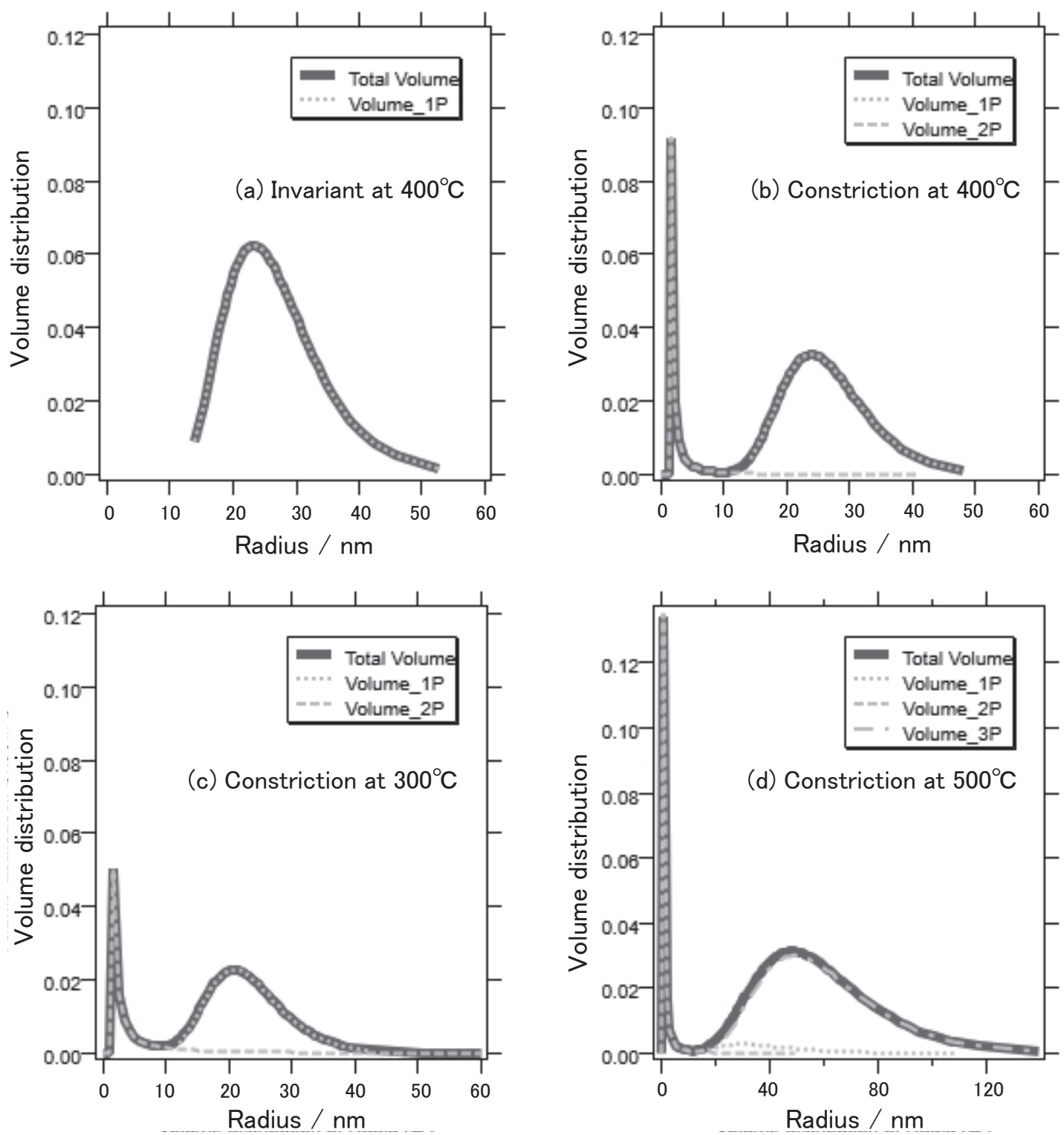

Fig. 4 Size distributions of precipitations derived from SAXS profiles in Fig. 3 (a) invariant at $400^{\circ} \mathrm{C}$, (b) constriction at $400^{\circ} \mathrm{C}$, (c) constriction at $300^{\circ} \mathrm{C}$ and (d) constriction at $500^{\circ} \mathrm{C}$.

組織が形成すると考えた。異なる $\{111\}$ 面にある2個の転位 の反応はローマー固着 (Lomer lock) 機構として知られ, 不 動転位化する現象として提案されている ${ }^{12)}$ 。また, HAADFSTEMで観察した $10 \mathrm{~nm}$ 以下の化合物は粒界にも析出して, 粒界の移動を抑止して再結晶を抑制するように作用したもの と考えられる。

熱間加工中の析出物を同定するため, 前報 ${ }^{7)}$ では $400^{\circ} \mathrm{C}$ 非 圧縮部と圧縮部のXRD測定（測定波長：0.8692 $\AA$ ）を行った。 その結果を Fig. 9 に示す。特徵的な点として，2 $2=26.5^{\circ}$ の回 折強度が非圧縮部より圧縮部で増加していることである。こ の回折は $\mathrm{Al}_{6} \mathrm{Mn}_{2} \mathrm{Si}_{5}$ の析出によるものと考えた。STEM-EDS 分析では Al-Mn-Si系三元化合物は観察できず, Al-Mn-Fe-Si 系四元化合物であった。再度, 本回折ピークの形成要因を検 討したところ， $2 \theta=26.5^{\circ}$ の回折ピークは $\mathrm{Al}_{9} \mathrm{Fe}_{0.84} \mathrm{Mn}_{2.16} \mathrm{Si}$ の (220) 面の回折ピークとほぼ重なることがわかった ${ }^{13)} 。$ Fig. 9 に $\mathrm{Al}_{9} \mathrm{Fe}_{0.84} \mathrm{Mn}_{2.16} \mathrm{Si}$ の回折ピーク位置を追記した。

これらのことから， $\mathrm{Al}-1 \% \mathrm{Mn}$ 合金の熱間加工で形成する析 出物はAl-Mn-Fe-Si系四元化合物と考える。今後, 鉄およびケ
イ素の存在量を変化させ, 熱間加工中の析出挙動や熱的安定 な下部組織形成への影響について調査する予定である。

\section{5. 結言}

$\mathrm{Al}-1 \% \mathrm{Mn}$ 合金を PSC 試験で熱間圧縮した部位の析出状態 を調査し, 以下の結果を得た。

(1) PSC 試験温度が高いほど, 圧縮部の導電率は高くなる。 非圧縮部も $500^{\circ} \mathrm{C}$ 加熱では導電率の上昇が認識できるが, 圧 縮部の方が導電率の上昇は大きい。 $\mathrm{PSC}$ 試験条件から, 約 0.5 秒の圧縮加工時間で析出が生じていると推定できる。

（2）小角散乱強度プロファイルの解析から, 圧縮部には 10 $\mathrm{nm}$ 以下の微細化合物が存在することがわかる。この微細化 合物は $300^{\circ} \mathrm{C}$ 圧縮部 $<400^{\circ} \mathrm{C}$ 圧縮部 $<500^{\circ} \mathrm{C}$ 圧縮部の順に多く なる。非圧縮部には, $10 \mathrm{~nm}$ 以下の微細化合物は確認できな い。

（3）STEM-EDS 分析から, 圧縮部で認識できる $10 \mathrm{~nm}$ 以下 の微細化合物はAl-Mn-Fe-Si系四元化合物である。 


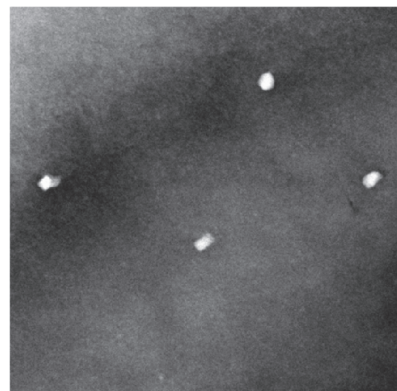

(a) Invariant at $400^{\circ} \mathrm{C}$

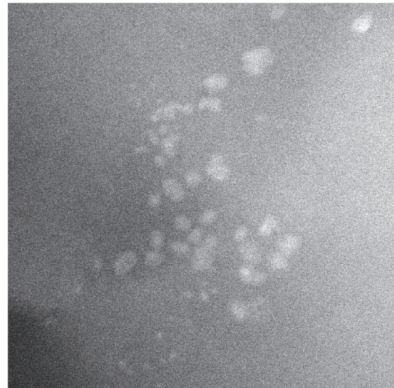

(c) Constriction at $300^{\circ} \mathrm{C}$

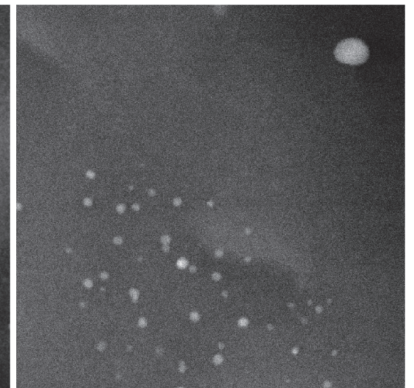

(b) Constriction at $400^{\circ} \mathrm{C}$

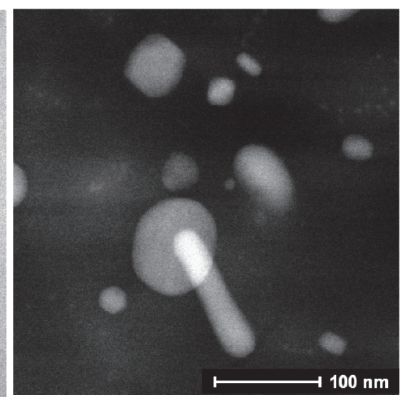

(d) Constriction at $500^{\circ} \mathrm{C}$

Fig. 5 STEM images after PSC test (a) invariant at $400^{\circ} \mathrm{C}$, (b) constriction at $400^{\circ} \mathrm{C}$, (c) constriction at $300^{\circ} \mathrm{C}$ and (d) constriction at $500^{\circ} \mathrm{C}$.
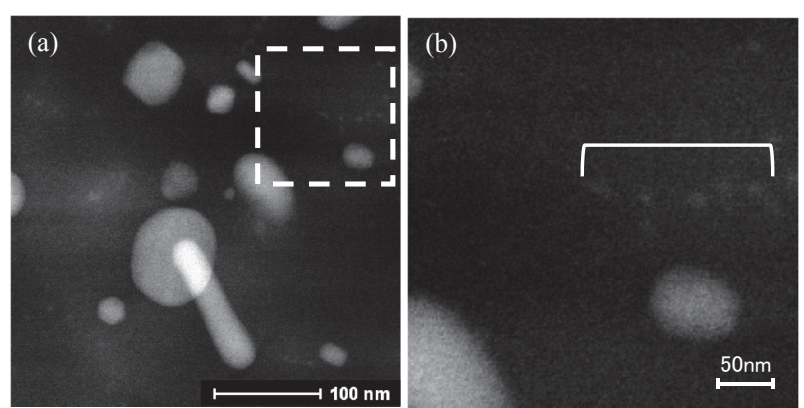

Fig. 6 STEM images (a) constriction at $500^{\circ} \mathrm{C}$ and (b) courtesy image of the broken line area in the left image.

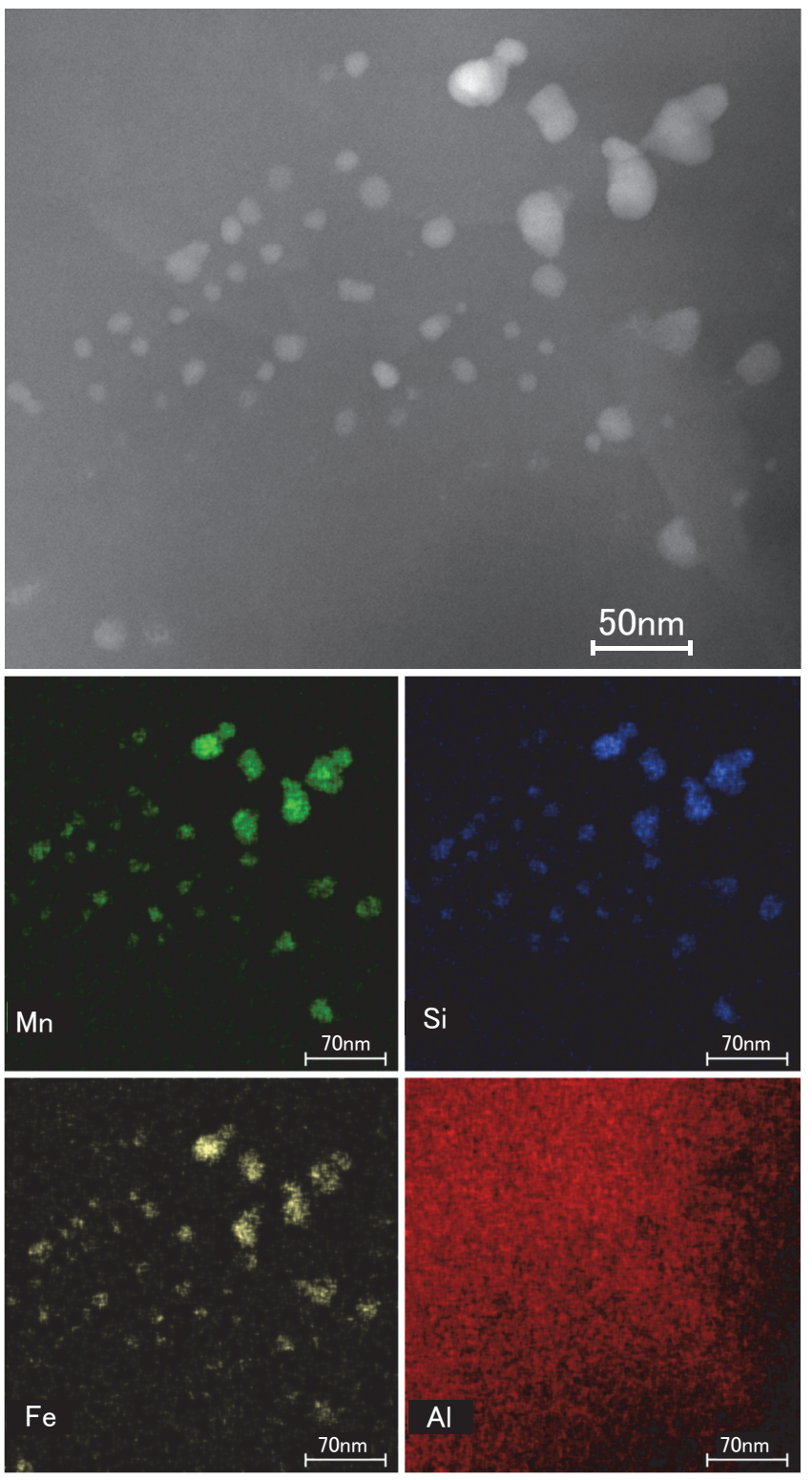

Fig. 7 STEM-EDS analyses on the constriction area at $400^{\circ} \mathrm{C}$.
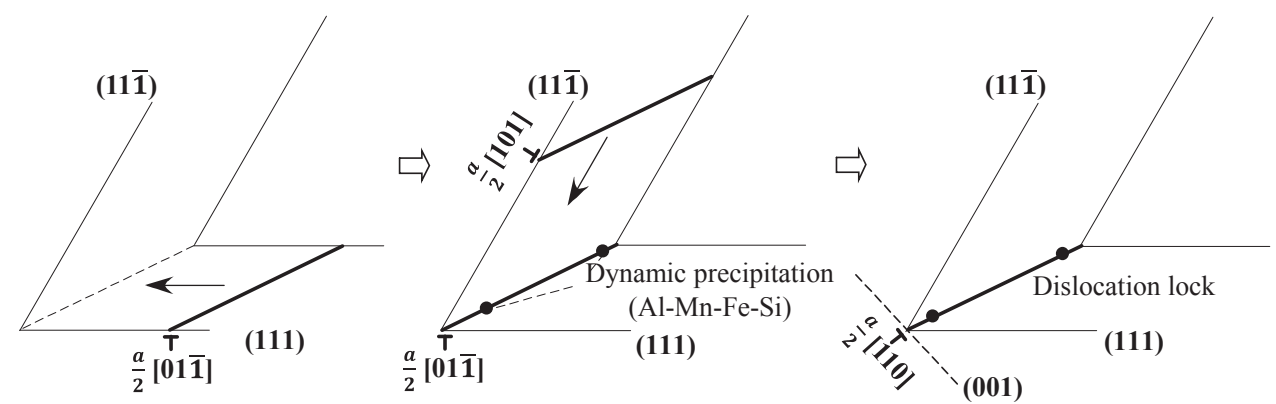

Fig. 8 Hypothesis on the formation of thermally stabilized substructures. $a$ : lattice constant. 


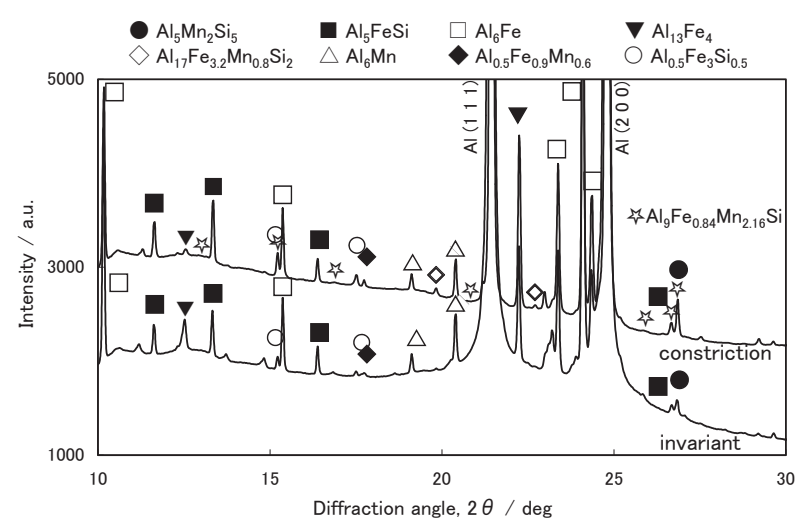

Fig. 9 X-ray diffractograms derived from the PSC specimens heated at $400^{\circ} \mathrm{C}$.

\section{謝 辞}

本成果の一部は「冷間/熱間加工工程における組織形成予測 部会」により得られたものです。関係者各位に深く感謝申し 上げます。STEM観察は産業技術総合研究所・齋藤徳之氏の 協力を得ました。ここに感謝申し上げます。

\section{参 考 文 献}

1) 鈴木太一，八太秀周：日本国特許第 6291133 号

2) H. Tanaka, Y. Nagai, Y. Oguri and H. Yoshida: Mater. Trans., 48 (2007), 2008-2013.

3) H. Tanaka and Y. Nagai: Proc. 15th Int. Conf. on Aluminum Alloys, Trans Tech Publications, (2017), 281-289.

4) 浅見重則, 土公武宜，八木啓介：軽金属，39（1989），94-100

5）箕田 正, 吉田英雄：軽金属, 47 (1997)，691-695.

6) 田中宏樹, 長井康礼：軽金属, 66 (2016), 2-8,

7) 田中宏樹, 成田 渉：軽金属, 69 (2019)，393-397。

8) 松岡秀樹：日本結晶学会誌, 41 (1999), 213-226.

9) J. Ilavsky and P. R. Jemian: J. Appl. Crystallogr., 42 (2009), 347-353.

10）山崎悟志, 大場洋次郎, 佐々木宏和, 大沼正人：古河電工時報, 137(2018)，46-51.

11) 齋藤 晃：日本結晶学会誌, 47 (2005), 9-14

12）中村正久：基礎転位論, 丸善株式会社, (1981), 90-92.

13) R. A. Brand, G. L. Caër, J. M. Dubois, F. Hippert, C. Sauer and J. Pannetier: J. Phys. Condens. Matter, 2 (1990), 3855-3865. 